\title{
最近の飽和脂肪酸の問題 Recent Topics for Saturated Fatty Acids
}

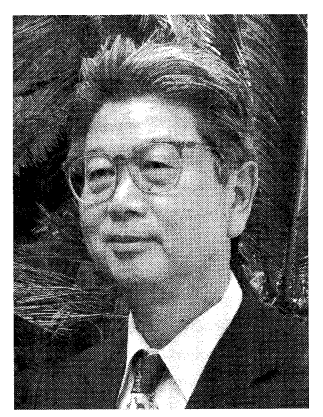

今泉勝已

九州大学大学院農学研究院生物機能科学部門

T812-8581

福岡市東区箱崎 6-10-1

Katsumi IMAIZUMI

Department of Bioresource and Bioenvironmental Sciences, Faculty of Agriculture, Kyushu University

6-10-1 Hakozaki, Higashi-Ku, Fukuoka 812-8581, JAPAN

論文要旨：トランス型モノ不飽和脂肪酸に代わり得る適切な脂肪を創ることが望まれている。動物やヒト の研究から，ステアリン酸は他の飽和脂肪酸， $12: 0,14: 0$ や $16: 0$ と比較してコレステロール代謝につい て異なった影響を及ぼすことが指摘されている。このような違いは, リノール酸に由来する摂取エネルギー の量によって影響を受けることから，よく制御された食事環境の基で血清コレステロールや動脈硬化に対す る影響を評価することが肝要である。ステアリン酸の恩恵的な効果は, 総コレステロール対 HDL コレステ ロール比を重回帰係数で評洒した， 60 例のメ夕分析によって確認されている。トリグリセリドの $s n-2$ 位に 存在する飽和脂肪酸は心臟疾患の危険因子に対して好ましくないとみなされてきたが， $s n-1(3)$ 位に飽和脂肪 酸が多いシアバターあるいはココアバターのエステル交換は食後高脂血症や血液凝固因子の濃度に対して恩 恵的であった。これらの研究は, トランス型モノ不飽和脂肪に代わるより優れた構造脂質の開発に寄与する であろう。

\begin{abstract}
It is looking forward to making an appropriate dietary fat instead of trans monounsaturated fats from the aspects of physical and physiological points. Animal and human experiments support the view that stearic acid is different from other saturated fatty acids such as 12:0, 14:0 and 16:0, in term of cholesterol metabolism. Such a difference is affected by an amount of ingested energy from linoleic acid, so that it is critical to evaluate the effect of controlled dietary environment on serum cholesterol and atherosclerosis. A beneficial effect of stearic acid was confirmed by the meta analyses from 60 studies in which a ratio of cholesterol to HDL cholesterol was estimated by regression analyses. Although triacylglycerols containing saturated fatty acid at $s n-2$ position have been considered to be unfavorable to the risk factor for heart diseases, interesterification of shear butter or cocoa butter which is enriched in saturated fatty acid at $s n-1(3)$ shows rather beneficial properties against postprandial hyperlipidemia and a coagulation factor level. These studies will contribute to develop better structured triacylglycerols instead of trans monounsaturated fats.
\end{abstract}

Key words: trans monounsaturated fats, stearic acid, linoleic acid, structured triacylglycerol

\section{1 はじめに}

食事脂肪は血漿リポタンパク質ーコレステロールの濃 度への影響を介して心臟疾患に影響することが知られて いる。とくに飽和脂肪酸は総コレステロールや低密度リ ポタンパク質（LDL）コレステロールを増加させること

連絡者: 今泉勝己

E-mail : imaizumi@agr.kyushu-u.ac.jp
からその摂取量を増やすことは好ましくないとされてき た。血漿脂質や心臟疾患との関係で取り上げられてきた 飽和脂肪酸は, 炭素数 12 18 である。一方, 飽和脂肪 酸は, 最近のトランス型脂肪酸の健康問題との関係で, 代替脂肪としての役割の観点から注目を浴びている。

本稿では, 飽和脂肪酸のこれまでの知見を踏まえつ つ，その好ましくない作用，好ましくないとは言えない 作用について, 筆者らの成績を含めて, 動物やヒトでの 
最近の知見を紹介する。

\section{2 動物}

\section{$2 \cdot 1$ 血漿脂質}

食事の総脂肪やコレステロールは血槳コレステロール 濃度に影響し，とくに，飽和脂肪酸の役割が重要である とされている。また，ヒトでは必ずしも明確にされてい ないが，それぞれの飽和脂肪酸が血漿コレステロール濃 度に異なった影響を及ぼすことが多数の動物実験での結 果から示唆されている。これらの実験結果を吟味する場 合，食事リノール酸や問題としている飽和脂肪酸のレベ ルとともに, 食事成分として置換することになる他の栄 養素のレベルにも注意を払うことが大切である ${ }^{1)}$ 。問題 にしている飽和脂肪酸の食事中のレベルは比較対象であ る食事中の脂肪と同じレベルであり，また，それらは妥 当な範囲のレベルでなければならない。八ムスター，カ ニクイザルに打いて，リノール酸の摂取量が高い （10.5\%エネルギー）時に，血漿コレステロール低下作用 があるとされているステアリン酸をパルミチン酸で $4 \%$ エネルギー分置換しても総コレステロールや LDL コレ ステロールの上昇はなかった2)。

一方，ラットやハムスターの実験では，ステアリン酸 はラウリン酸, ミリスチン酸あるいはパルミチン酸に比 べて血漿コレステロール濃度を増加させないと報告され ている。脂肪のエネルギー\%が 20.1, その内, リノール 酸と飽和脂肪酸のエネルギー\%がそれぞれ $3.5 \sim 4.6$ と 9.2 11.2 の食事脂肪をハムスターに与えた筆者らの実験 では，食事にコレステロールが含まれないときにはステ アリン酸型脂肪食で, 他の飽和脂肪酸型脂肪食と比較し て，血漿コレステロールの低下が認められている。な お，食事脂肪は，飽和脂肪酸：オレイン酸：リノール 酸 $=5: 3: 2$ となるように，飽和脂肪酸 $(12: 0,14: 0$, $16: 0,18: 0$ のいずれかひとつ)：ハイオレイックサフ ラワー油，大豆油の混合物をエステル交換したものを用 いた ${ }^{3)}$ (Table 1)。この場合，ステアリン酸型食事脂肪の
Table 1 Effects of Different Saturated Fatty Acids on the Concentration of Plasma Cholesterol in Hamsters Fed Diets with or without Cholesterol.

\begin{tabular}{lcc}
\hline Group & $\begin{array}{c}\text { Cholesterol-free } \\
\text { diets }\end{array}$ & $\begin{array}{c}\text { Cholesterol-containing } \\
\text { diets }\end{array}$ \\
\hline mmol/L & $\mathrm{mmol} / \mathrm{L}$ \\
$14: 0$ & $5.95^{\mathrm{b}}$ & 7.19 \\
$16: 0$ & $6.18^{\mathrm{b}}$ & 7.88 \\
$18: 0$ & $5.48^{\mathrm{b}}$ & 7.63 \\
Pooled SE & $4.63^{\mathrm{a}}$ & 7.53 \\
\hline
\end{tabular}

Six animals per group.

${ }^{\mathrm{ab}}$ Different superscript letters are significantly different at $P<0.05$.

効果は脂肪吸収過程に影響して発揮された。なお，食事 に含まれるコレステロールの量も結果の解釈に影響す る。多くの動物実験では，コレステロール摂取量が多い ほど飽和脂肪酸は LDL コレステロールを増加させる傾 向がある。上述のハムスター，カニクイザルの成績と ラット，八ムスターを用いた筆者らの成績の違いは，あ るレベル以上のリノール酸（間值）が食事に存在する と, 飽和脂肪酸の血漿コレステロール上昇効果が排除さ れるという考え方で説明が可能である ${ }^{1)}$ 。換言すると， それぞれの飽和脂肪酸は血漿コレステロール濃度に異 なった影響を及ぼすけれども, リノール酸の食事レベル が低いときには，各種の飽和脂肪酸は一様に血槳コレス テロール上昇的となる。

\section{$2 \cdot 2$ 動脈硬化}

食事の飽和脂肪酸をリノール酸で置換することは，動 脈硬化の危険因子であると見なされている LDL コレス テロールを低下させることが出来るという恩恵的な効果 が期待される反面，リノール酸に富む食事は体内の酸化 ストレスや炎症反応を充進する可能性がある。ヒトに類 似の動脈硬化病変を呈することが知られているアポE欠 損マウスを用いて，飽和脂肪酸（1 kg 飼料あたり，パー ム油 $50 \mathrm{~g}$ とラード $50 \mathrm{~g}$ を含む）あるいはリノール酸に

Table 2 Effect of Dietary Saturated Fatty Acid-rich Fat (SF) and Linoleic Acid-rich Fat (HL) on Atherosclerotic Lesion, Serum Cholesterol (Cho), Urinary Isoprostanes (15-F2t-IsoP-M) for Female and Male Apolipoprotein E-deficient Mice.

\begin{tabular}{|c|c|c|c|c|c|}
\hline & \multicolumn{2}{|c|}{ Female } & \multicolumn{2}{|c|}{ Male } & \multirow{2}{*}{$\begin{array}{c}\text { ANOVA } \\
\text { (Fat) }\end{array}$} \\
\hline & SF & HL & $\mathrm{SF}$ & $\mathrm{HL}$ & \\
\hline Lesion size $\left(\mathrm{mm}^{2}\right)$ & $0.25^{\mathrm{a}}$ & $0.146^{\mathrm{b}}$ & $0.271^{\mathrm{a}}$ & $0.136^{\mathrm{b}}$ & 0.01 \\
\hline Serum Total Cho $(\mathrm{mmol} / \mathrm{L})$ & $22.2^{\mathrm{b}}$ & $14.9^{\mathrm{c}}$ & $31.0^{\mathrm{a}}$ & $25.6^{\mathrm{ab}}$ & 0.01 \\
\hline Serum HDL Cho $(\mathrm{mmol} / \mathrm{L})$ & $0.68^{b}$ & $1.19^{\mathrm{a}}$ & $0.69^{b}$ & $1.19^{\mathrm{a}}$ & 0.01 \\
\hline $\begin{array}{l}\text { Urine } 15-\mathrm{F} 2 \mathrm{t}-\mathrm{IsoP}-\mathrm{M} \\
(\mathrm{ng} / \mu \text { mol creatinine })\end{array}$ & $2.12^{\mathrm{a}}$ & $2.42^{\mathrm{a}}$ & $0.53^{b}$ & $1.55^{\mathrm{a}}$ & 0.01 \\
\hline
\end{tabular}

Mean values for $7-8$ mice per sex for each group.

abc Different letters are significant different at $P<0.05$. 
富む油脂（1 kg 飼料あたり，高リノール酸含有サフラ ワー油を $100 \mathrm{~g}$ 含む）の動脈硬化の進展に及ぼす影響を 検討した ${ }^{4)}$ 。動脈硬化病変面積は飽和脂肪酸食で, リ ノール酸食と比較して増加した（Table 2）。酸化ストレ スのマーカーである尿中のイソプロスタン（15-F2t-IsoP$\mathrm{M}=2,3$-dinor-5,6-dihydro-8-iso-prostaglandin $\mathrm{F} 2 \alpha$ ) 排泄量や大動脈における炎症反応の指標である単球遊走 因子-1（MCP-1）の mRNA レベルはリノール酸食で 大きかった。一方, 血漿総コレステロール濃度はリノー ル酸食で低く, HDL コレステロール濃度は飽和脂肪酸 食で低かった。なお，リノール酸食にコレステロールを 添加することによって飽和脂肪酸食と血清コレステロー ルレベルが同じ程度に高くなるようにしたところ，動脈 硬化病変は両食事間で違いが見られなかった。これらの 結果から，アポE 欠損マウスでは血漿と動脈壁との間の コレステロール輸送が動脈硬化の進展を決定づける最も 重要な要因であることが示唆される。

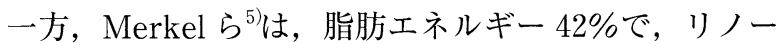
ル酸に富む食事（飽和脂肪酸：モノ不飽和脂肪酸：多価 不飽和脂肪酸 $=8: 8: 26 ）$ あるいは飽和脂肪酸に富む 食事（飽和脂肪酸：モノ不飽和脂肪酸：多価不飽和 $=$ 30：8：4）を与えたLDL レセプター欠損マウスでは, 動脈硬化の病変の程度に差が認められなかった。更に， 予想に反して，飽和脂肪酸に富む食事は，オレイン酸に 富む食事（飽和脂肪酸：モノ不飽和脂肪酸：多価不飽 和 $=8: 30: 4)$ あるいは炭水化物に富む食事（脂肪工 ネルギー $20 \%$ ）と比較して，病変の程度は軽減するこ とが観察されている。飽和脂肪酸に富む食事と多価不飽 和脂肪酸に富む食事を与えたマウスではモノ不飽和脂肪 酸や炭水化物に富む食事と比較して，血漿総コレステ ロールとVLDL コレステロール濃度が低いことが病変
の違いに関係しているようであった。なお，これらの食 事をアポE 欠損マウスに与えた場合には，血漿コレステ ロールの応答は LDL レセプター欠損マウスと類似の影 響が観察されたが，動脈硬化病変の程度には顕著な差異 は見られなかった。この結果は, 前述のアポ $\mathrm{E}$ 欠損マウ スでの成績とは異なっている。

リノール酸に富む食事が飽和脂肪酸に富む食事と比較 して動脈硬化の進展に対して好ましい影響をもたらすこ とは，アフリカ緑サルやヒトのアポ $\mathrm{B}$ タンパク質を過剩 発現する LDL レセプター欠損マウスで観察されている ${ }^{6)}$ しかし，これらの動物では，オレイン酸に富むサフラ ワー油を与えた場合には，飽和脂肪酸に富む食事を与え た動物と同じ程度に，血漿低密度リポタンパク質画分の エステル型コレステロールの濃度が増加し，また，病変 の進展が観察されている。

飽和脂肪酸食に対する動脈硬化の進展の応答がこのよ うに異なる原因は，欠損遺伝子の違いに加えて，遺伝子 欠損手法の違い, 動物の週齢や飼料組成などの違い等に 基づくものと思われる。

\section{$2 \cdot 3$ 中鎖脂肪酸を含む構造脂質の吸収と代謝}

食事脂肪は様々な種類の立体異性体トリグリセリドを 含む。例えば，乳脂肪中のパルミチン酸はグリセロール 分子上の $s n-2$ 位に, リノール酸は $s n-1$ と-3 位に存在 する。植物油や他の脂肪の多くではパルミチン酸は $s n-1$ と-3 位に存在し, リノール酸は $s n-2$ 位に存在す る。ラードは, 例外的に, パルミチン酸は $s n-2$ 位に存 在する。これらの立体構造上の特徵は吸収過程と小腸細 胞内でのトリグリセリドの再構築の際に保持される。

中鎖脂肪酸は胃で速やかに吸収されると考えられてい るが，かなりの量が小腸から吸収され，キロミクロンと してリンパ系から血中へと輸送される7)。Table 3 はこの

Table 3 Distribution of 8:0, 10:0 and 18:2 at $s n-2$ Position of Structured Triacylglycerols in Diet and Lymph.

\begin{tabular}{ccccc}
\hline $\begin{array}{c}\text { Fatty } \\
\text { Acids }\end{array}$ & MLM $(s n-2)$ & $\begin{array}{c}\text { iMLM }(s n-2) \\
(\mathrm{mol} \%)\end{array}$ & LML $(s n-2)$ & iLML $(s n-2)$ \\
\hline Diet & 1.5 & 8.4 & 22.8 & 15.8 \\
$8: 0$ & 1.2 & 6.6 & 19.0 & 12.9 \\
$10: 0$ & 36.4 & 25.1 & 5.7 & 16.3 \\
$18: 2(\mathrm{n} 6)$ & & & & \\
Lymph & 0.9 & 2.1 & 4.2 & 3.1 \\
$8: 0$ & 1.0 & 3.7 & 12.9 & 5.7 \\
$10: 0$ & 35.8 & 24.3 & 13.3 & 19.6 \\
$18: 2(\mathrm{n} 6)$ & &
\end{tabular}

MLM: 8:0 and 10:0 are mainly distributed at the $s n-1$ and -3 and linoleic acid at the $s n-2$.

LML: 8:0 and 10:0 are mainly distributed at the $s n-2$ and linoleic acid at the $s n-1$ and -3 .

iMLM and iLML: interesterified products of MLM and LML, respectively. 
ような関係を示している。すなわち， $s n-2$ と $s n-1,3$ 位 に中鎖脂肪酸あるいはリノール酸を多く含む立体異性体 トリグリセリド（MLM と LML）およびそれらのエステ ル交換体（iMLM と iLML）を食事としてラットに与 え,リンパ中のキロミクロンを回収しそれらの脂肪酸組 成を測定した。 $s n-2$ 位に存在する中鎖脂肪酸やリノー ル酸はリンパのトリグリセリド中でも位置特異性が高 い。なお，中鎖脂肪酸を $s n-2$ 位に含む LML は他の脂 肪と比較して血中での異化速度が遅い。 MLM, iMLM, LML, iLML の血中での半減期はそれぞれ（14.1，13.0， 18.7, 14.0 分）であった。

\section{3 ヒト}

\section{$3 \cdot 1$ 血漿脂質とリポタンパク質}

ヒトと動物はコレステロール代謝においていくつかの 重要な違いがある。一般に，コレステロール合成はヒト では厳密に制御されており，合成と吸収は連動して体内 のコレステロールプールを調節している。多くの動物実 験は食事コレステロールに対して好ましくない方向に応 答するが，ヒトでは，食事コレステロールが血漿コレス テロール濃度へ及ぼす影響は小さい。リポタンパク質の 構造と機能も動物とヒトでは大きく異なり，ヒトは LDL，動物はHDL がそれぞれ主要なコレステロール輸 送体である。

ヒトでの成績は一般に動物よりも一定しないことが多 い。遺伝因子とともに，環境因子を制御することが難し いことが関係している。したがって，ヒトでの結果を比 較する場合にはこのような背景を考慮して解析すること が肝要である。

血漿コレステロール濃度は，これまで，食事脂肪を評 価する際に有用な冠状動脈疾患の危険因子のひとつとみ なされてきた。とくに，乳脂肪や熱带産油脂に多いラウ リン酸，ミリスチン酸やパルミチン酸に富む脂肪は健康 に悪いとされ，脂肪が少なく，炭水化物に富む食事が健 康に適しているとされてきた。一方，食事を介して
HDL コレステロール濃度を増加させることは冠状動脈 疾患の危険性を低下させることが，多くの報告で指摘さ れている。実際，総コレステロール対 HDL コレステ ロール比は冠状動脈疾患の危険性を評価する際に，総コ レステロールやリポタンパク質態コレステロールよりも より重要であると考えられている。そこで, Mensink ら ${ }^{8)}$ は，心臓疾患に好ましくない影響をもたらす LDL コレ ステロールと恩恵的に作用する HDL コレステロールの レベルを同時に評価する方法として，個々の脂肪酸の総 コレステロール対 HDL コレステロール比について 60 例 の研究についてメ夕分析を行い, 重回帰式を導き出し, それが実測值と一致することを証明した（Table 4）。 $1 \%$ エルギーの炭水化物を同じエネルギーの飽和脂肪 酸で置換した時はこの比は変わらなかったが，不飽和脂 肪酸で置換した時はこの比は低下した。トランス型モノ エン酸での置換は他の脂肪酸と比較して総コレステロー ル対 HDL コレステロール比を最も大きくした。ラウリ ン酸での置換は HDL コレステロールを上昇させるため, 総コレステロール対 HDL コレステロール比を低下させ た $(-0.037, P<0.001)$ 。ミリスチン酸やパルミチン酸 はこの比に影響しない $(-0.003, P=0.832,0.005, P=$ 0.431）が，ステアリン酸での置換は低下させる傾向が

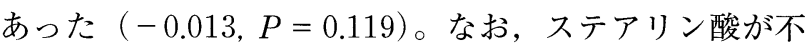
飽和脂肪酸のように総コレステロールを低下させる傾向 があることは，健康な被験者を用いたクロスオーバー試 験でも見出されており，ほぼ7\%のエネルギーがステア リン酸，オレイン酸，リノール酸から 5 週間摂取される 条件だと，血漿脂質やリポタンパク質のレベルはほぼ同 じレベルであった ${ }^{9)}$

ところで，血漿 HDL コレステロールが低い，トリグ リセリド濃度が高いあるいはインスリンレベルが高い等 の代謝的に異常があり，臨床的なアドバイスが緊急に必 要なヒトに対して，飽和脂肪酸に富む脂肪の代わりに炭 水化物あるいはモノ不飽和脂肪酸に富む脂肪のいずれが 良いのであろうか。最近の DELTA プログラム

Table 4 Predicted Change $(\Delta)$ in the Ratio of Serum Total to HDL Cholesterol and in LDL- and HDL-cholesterol (Cho) Concentrations when Carbohydrates Constituting 1\% Energy Are Replaced Isoenergetically with Saturated (SFAs), cis Monounsaturated (MUFAs), cis Polyunsaturated (PUFAs) and trans Monounsaturated (trans) fatty acids.

\begin{tabular}{lrrrr}
\hline \multicolumn{1}{c}{ Lipoproteins } & SFAs & MUFAs & PUFAs & trans \\
\hline$\Delta$ Total:HDL Cho & 0.003 & -0.026 & -0.032 & 0.022 \\
$P$ & 0.613 & $<0.001$ & $<0.001$ & 0.015 \\
$\Delta$ LDL Cho $(\mathrm{mmol} / \mathrm{L})$ & 0.032 & -0.009 & -0.019 & 0.040 \\
$P$ & $<0.001$ & 0.004 & $<0.001$ & 0.002 \\
$\Delta$ HDL Cho $(\mathrm{mmol} / \mathrm{L})$ & 0.010 & 0.008 & 0.006 & 0.000 \\
$P$ & $<0.001$ & $<0.001$ & $<0.001$ & 0.937 \\
\hline
\end{tabular}


(Dietary Effects on Lipoproteins and Thrombogenic Activity）からの報告は次のとおりである。男性 55 人, 女性 33 人について 7 週間間隔で，3回のクロスオー バー実験が行われた。被験者は平均的なアメリカ人の食 事（36\%脂肪エネルギー）を摂取し，そのうちの $7 \%$ の 飽和脂肪酸分が炭水化物あるいはモノ不飽和脂肪酸で置 換された ${ }^{10)}$ 。その結果，炭水化物食とモノ不飽和脂肪食 は LDL コレステロールをそれぞれ-7.0\%，-6.3\%低下 させたが, HDL コレステロールの低下は炭水化物食で 大きく，血漿トリグリセリドの増加はモノ不飽和脂肪食 で少なかった。なお，心臓疾患の危険因子の一つである リポプロテイン (a) $[\mathrm{Lp}$ (a)] の濃度は炭水化物食で $20 \%$, モノ不飽和脂肪食で $11 \%$ 増加していた。これらの結果 に基づいて，DELTA プログラムでは，冠状動脈疾患の 危険性が高いヒトには，食事の飽和脂肪酸を置換する場 合, モノ不飽和脂肪食が炭水化物食よりも適していると 結論している。

食事脂肪と動脈硬化の進展との関係を調べたヒトでの 報告は少ない。心血管疾患の危険因子である飽和脂肪や トランス型脂肪の摂取と頸動脈の内膜肥厚を指標として 620 人の先住民，カナダ在住の南アジア人，中国人，欧 州人について無症候性動脈硬化との関係を調べたカナダ からの報告 ${ }^{11)}$ によると，通常の摂取量よりも $10 \mathrm{~g} /$ 日多 い飽和脂肪の摂取と $1 \mathrm{~g} /$ 日多いトランス型脂肪酸の摂取 はそれぞれ独立に内膜の肥厚を促進した $(0.03 \mathrm{~mm}) 。-$ 方, 多価不飽和脂肪食の摂取は内膜の肥厚と逆相関 $(-0.06 \mathrm{~mm})$ の関係にあった。

HDL は，抗炎症作用を有し，サイトカインで刺激さ れた内皮細胞による接着分子の発現を in vitroで抑制す ることが知られているが，このような HDL の機能と食 事脂肪の摂取との関係について調查は少ない ${ }^{12)}$ 。 Nicholls $ら^{13)}$ は 14 人の成人に同じカロリーの多価不飽和脂肪酸 (サフラワー油) に富む食事あるいは飽和脂肪酸（ヤシ 油）に富む食事を与え，それぞれ，食前と食後の. 3 時間 と 6 時間後に採血し，HDL を調製した。飽和脂肪酸食 摂取 6 時間後に得られた HDL は，絶食後に得られた HDL と比較して，ヒト静脈内皮細胞における内皮細胞 接着因子（ICAM-1 と VCAM-1）の発現量を抑制する 能力が低かったが，多価不飽和脂肪酸摂取後に得られた HDL は絶食後の HDL のそれよりも抑制効果が大であっ た。これらの知見は, 食事脂肪は従来検討されてこな かった動脈硬化の主要なプロセスに対して影響すること を示している。

\section{$3 \cdot 2$ 食後高脂血症}

ランダムエステル交換は部分水添油脂の代替物として 融点が高い硬化脂肪製造の目的で行われるが，ヒトにお
ける心臓血管疾患の危険因子に対するランダムエステル 交換脂肪の影響は必ずしも明らかではない。植物油中の 飽和脂肪酸（パルミチン酸, ステアリン酸）はトリグリ セリド分子の外側 $(s n-1, s n-3)$ に位置している。植物 油のランダム化は, $s n-2$ 位に飽和脂肪酸が多い, ラー ドのような分子種を生じる。動物や乳児における研究か ら，飽和脂肪酸は， $s n-2$ 位にある場合は， $s n-1, s n-3$ 位にある場合と比較して 2-モノグリセリドとして効率 よく吸収される。一方， $s n-1, s n-3$ の飽和脂肪酸は遊 離脂肪酸としてカルシウムやマグネシウムと石鹸を生じ るため，吸収率が悪いとみなされている。さらに，sn-2 位に存在する飽和脂肪酸はキロミクロントリグリセリド に保持され, 血漿中では緩やかに異化されるため, 動脈 硬化の危険因子のひとつである食後の高脂血症を伴うと みなされてきた。この考え方は，1,2 di-oleyl-stearyl glycerol (OOS) と 1,3-di-oleyl-stearyl glycerol (OSO) を用いた研究では支持されていない ${ }^{14)}$ 。なお，2 分子の ステアリン酸がトリグリセリドに含まれる場合について は，上記の考え方を適用できない。いずれにしても，飽 和脂肪酸に富む脂肪のランダムエステル交換はトリグリ セリドにおける脂肪酸の位置分布や脂肪の物性を変化さ せる。

食後高脂血症と食事トリグリセリド構造との関係につ いて，イギリスのグループは次のような一連の研究を行 い，パルミチン酸やステアリン酸に富むエステル交換植 物油は食後の高脂血症や血液凝固因子（FVIIa）への影 響が従来の知見とは異なっていることを示している。

Berry ら ${ }^{14)}$ は, 1,3-distearyl,2-oleyl glycerol (SOS) に富む脂肪（シアバターとヒマワリ油との混合物で， SOS, SSO, SSS をそれぞれ 76.2, <0.1, 2.7\%含む) のエス テル交換脂肪（SOS, SSO, SSSをそれぞれ 46.3, 15.8, 10.1\%を含む）を作製し，絶食時と食後の血漿脂質，グ ルコース，インスリン，血液凝固因子（FVIIa）への急 性と慢性の影響を調べた。16人の男性についてクロス オーバーデザインで，3 週間，シアバターとヒマワリ油 混合物とそれらのエステル交換物を試験食として与え た。これら脂肪は約 50\%のステアリン酸（エネルギー 比で 1 日 7\%摂取）を含んでいた。混合油とエステル交 換油は同じ程度に消化・吸収された。ランダム化は絶食 時と食後の脂質，グルコース，インスリン，FVIIa 濃度 に影響しなかった。一方，オレイン酸に富むヒマワリ油 と比較して，シアバターとヒマワリ油混合物摂取に基づ く食後の脂質レベル増加は 53\%，FVIIa の増加は $25 \%$ ，

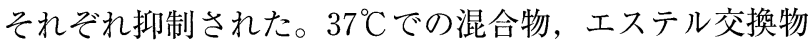
とオレイン酸に富む油脂の固体脂肪含量はそれぞれ 22\%，41\%，0\%であった。混合物やそのエステル交換 
物とオレイン酸に富む油脂の食後高脂血症に対する応答 の違いは, 前者で生じている結晶性の固体脂肪が消化管 でのミセル形成に影響し，ひいては，消化と吸収を遅延 させたと考えられる。これらの結果は，ステアリン酸に 富む脂肪は，ランダム化あるいは非ランダム化にかかわ らず心血管疾患の危険因子に悪い影響はもたらさないこ とを示している。

なお，これらの結果は, Sanders ら ${ }^{15}$ が，ココアバ ター（POS, SOS, POP, SOO をそれぞれ 44.0, 27.5, 15.4, $3.1 \%$ 含む）とそのエステル交換物（POS, SOS, POP, SOO をそれぞれ 21.0，12.2，15.1，12.3\%含む）を用いたヒ トでの結果とは異なっている。すなわち, ココアバ夕ー とそのエステル交換物では食後 6 時間での高脂血症は後 者で $41 \%$ 低かった。また, FVIIa は後者では増加しな かったが，ココアバターでは増加した。

さらにBerry ら ${ }^{16}$ は，パルミチン酸に富む脂肪の食後 の高脂血症と FVIIa 濃度への影響を調查した。健常男性 に $50 \mathrm{~g}$ のパーム油（sn-2 位のパルミチン酸とオレイン 酸はそれぞれ 7.2 と $70.9 \%)$ ，エステル交換パーム油 (sn-2 位のパルミチン酸とオレイン酸は 37.2 と $45.3 \%)$, 高オレイン酸含有ヒマワリ油 $(s n-2$ 位のパルミチン酸 とオレイン酸は 0 と $91.2 \%)$ を摂取させ，3 時間と 6 時 間後に採血した。エステル化パーム油はパーム油と比較 して食後の高脂血症を抑制した。高オレイン酸含有ヒマ ワリ油と比較して，エステル交換パーム油は食後高脂血 症と FVIIa の増加を抑制した。このようなエステル交換

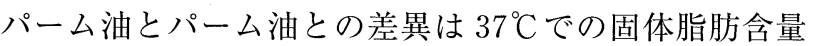
の違いが関係している可能性がある（エステル交換体， パーム油, オレイン酸高含有ヒマワリ油の固体脂肪含量 はそれぞれ，15，4 と0\%)。これらの結果は，パルミチ ン酸に富む脂肪のエステル交換は，好ましくない影響を 及ぼすものではないということを示している。

これら三つのヒトでの実験から，sn-2 位に飽和脂肪 酸が多い油脂は食後高脂血症や FVIIa の上昇に対して抑 制的に作用することを示している。

\section{$3 \cdot 3$ リノール酸の摂取レベルとの関係}

米国の研究者 ${ }^{1}$ が提案したリノール酸の閾值効果に依 ると，食事のリノール酸のレベルが $6 \%$ エネルギー以上 であれば，パルミチン酸の摂取は健常者の LDL コレス テロール濃度に影響しない。カナダ人が対象であるが， 21 日のクロスオーバーデザインに基づいて行われた健 常男性を用いた実験では，高レベルのパルミチン酸の摂 取（12\%エネルギー）は，リノール酸の撕取レベルが推 奨量の範囲（8～9\%エネルギー）であれば，血漿総コレ ステロールと LDL コレステロール濃度に影響しない。 また，内因性のコレステロール合成と食事のパルミチン
酸の摂取量との間にも一定の関係は見いだされていな い。リノール酸の食事中のレベルが $4.5 \%$ エネルギー以 上であればパルミチン酸の摂取レベルが高くても血漿コ レステロールの上昇は観察されていない。

高脂血症の被験者を対象とした実験では，食事のパル ミチン酸の影響は観察されなかったが，部分水添脂肪に 由来するトランス型脂肪酸は血漿コレステロール，LDL コレステロール，内因性コレステロール合成を上昇させ た ${ }^{1)}$ 。飽和脂肪酸は，食事中のモノ不飽和脂肪酸や多価 不飽和脂肪酸と置換した場合, 血漿 HDL コレステロー ルレベルを上昇あるいはそれに影響しないとされている が，少量のトランス型脂肪酸は HDL コレステロールを 減少させる傾向が強い。

\section{4 結論と展望}

トランス型脂肪酸に代わる好ましい物性と生理作用を 兼ね備えた脂肪が待望されている。動物実験やヒトでの 成績から，ステアリン酸のコレステロール代謝への影響 はパルミチン酸，ミリスチン酸，ラウリン酸とは異なる ことが示されている。しかし，このような差異もリノー ル酸の摂取エネルギーレベルの影響を大きく受けること から，血漿コレステロール濃度や動脈硬化に及ぼす食事 の影響を評価する場合は十分吟味した食環境の準備が必 要である。

ヒトでの 60 の実験例を取りまとめてメ夕分析を行い, 得られた重回帰式から推定される総コレステロール対 HDL コレステロールの比から，ステアリン酸は他の飽 和脂肪酸とは異なる恩恵的な作用を発揮することが示さ れている。sn-2 位にステアリン酸が多いトリグリセリ ドは心疾患の危険因子に対して好ましくないとされてき たが，シアバターやココアバターのエステル交換物は食 後高脂血症や FVIIa のレベルに対してむしろ好ましい作 用を示す。

これらのヒトや動物実験での成績は，トランス型脂肪 酸の代替物としてステアリン酸を含む構造脂質の今後の 開発に期待を寄せさせる。

\section{文献}

1) M.S. Wilke \& M.T. Clandinin, Lipids, 40, 1207 (2005).

2) S.V. Gupta \& P. Khosla, J. Nutr., 131, 2115 (2001).

3) K. Imaizumi, K. Abe, C. Kuroiwa \& M. Sugano, J. Nutr., 123, 1693 (1993).

4) M. Sato, K. Shibata, R. Nomura, D. Kawamoto, R. Nagamine \& K. Imaizumi, Br. J. Nutr., 94, 896 (2005).

5) M. Merkel, W. Velez-Carrasco, L.C. Hudgins \& J.L. Breslow, Proc. Natl.Aca. Si, U.S.A., 98, 13294 (2001).

6) L.L. Rudel, K. Kelley, J.K. Sawyer, R. Shah \& M.D. Wilson, Arterioscler. Thromb. Vasc. Biol., 18, 1818 (1998). 
7) T. Kishi, O. Carvajal, H. Tomoyori, I. Ikeda, M. Sugano \& K. Imaizumi, Nutr. Res., 22, 343 (2002).

8) R.P. Mensink, P.L. Zock, A.D.M. Kester \& M.B. Katan, Am. J.Clin. Nutr., 77, 1146 (2003).

9) M.A. Thijssen \& R.P. Mensink, Am. J. Clin. Nutr., 85, 510 (2005).

10) L. Berglund, M. Lefevre, H.N. Ginsberg, P.M. Kris-Etherton, P.J. Elmer, P.W. Stewart, A. Ershow, T.A. Pearson, B.H. Dennis, P.S. Roheim, R. Ramakrishnan, R. Reed, K. Stewart \& K.M. Phillips, Am. J. Clin. Nutr., 86, 1611 (2007).

11) A.T. Merchant, L.E. Kelemen, L. de Koning, E. Lonn, V.
Vuksaan, R. Jacobs, B. Davis, K.K. Teo, S. Yusuf \& S.S. Anand, Am. J. Clin. Nutr., 87, 168 (2008).

12) I.M. Singh, M.H. Shishehbor \& B.J. Ansell, JAMA, 298, 786 (2007).

13) S.J. Nicholls, P. Lundman, J.A. Harter \& D.S. Celermajer, J. Am. College Cardiol., 48, 715 (2006).

14) S.E.E. Berry, R. Woodward, C. Yeoh, G.J. Miller \& T.A.B. Sanders, Lipids, 42, 315 (2007).

15) T.A.B. Sanders, S.E.E. Berry \& G.J. Miller, Am. J. Clin. Nutr., 77, 777 (2003).

16) S.E. Berry, R. Woodward, C. Yeoh, G.J. Miller \& T.A.B. Sanders, Lipids, 42, 315 (2007). 